This item was submitted to Loughborough's Research Repository by the author.

Items in Figshare are protected by copyright, with all rights reserved, unless otherwise indicated.

\title{
Fandom in the workplace: Multi-target identification in professional team sports
}

PLEASE CITE THE PUBLISHED VERSION

http://dx.doi.org/10.1123/JSM.2014-0132

\section{PUBLISHER}

(c) Human Kinetics Publishing as accepted for publication

\section{VERSION}

AM (Accepted Manuscript)

\section{PUBLISHER STATEMENT}

This work is made available according to the conditions of the Creative Commons Attribution-NonCommercialNoDerivatives 4.0 International (CC BY-NC-ND 4.0) licence. Full details of this licence are available at: https://creativecommons.org/licenses/by-nc-nd/4.0/

\section{LICENCE}

CC BY-NC-ND 4.0

\section{REPOSITORY RECORD}

Swanson, Steve, and Aubrey Kent. 2015. "Fandom in the Workplace: Multi-target Identification in Professional Team Sports". Loughborough University. https://hdl.handle.net/2134/20607. 


\title{
Fandom in the Workplace: Multi-Target Identification in Professional Team Sports
}

\author{
Steve Swanson \\ Aubrey Kent
}

\begin{abstract}
Team identification has been researched extensively from the perspective of the consumer. The current study proposes that employees working in professional sport may also be fans of their respective teams, and provides insight on the role of team identification in the workplace environment. Over 1100 business operations employees from the top profession sports leagues in North America participated, and results indicate that dual targets of identification exist simultaneously in this setting. Strong support is provided for the discriminant validity between organizational and team identification. Beyond the more established effects of organizational identification, the results provide evidence that team identification independently predicts key outcomes such as commitment, satisfaction, and motivation. The results add to the literature by introducing the concept of a sports team as an additional target of identification in the organizational context.
\end{abstract}




\section{Fandom in the Workplace: Multi-Target Identification in Professional Team Sports}

The concept of identifying with a collective of individuals has been widely researched in mainstream management literature. In particular, assessing the degree to which employees identify with their respective organizations has been studied for nearly three decades, with organizational identification now positioned as a key organizational construct (Ashforth, Harrison, \& Corley, 2008; Riketta, 2005). An increasingly interesting aspect of organizational identification is that individuals are capable of simultaneously identifying with multiple entities of their organizational environment such as workgroups, departments, and committees, in addition to the organization as a whole (e.g., Ashforth \& Johnson, 2001). These facets of an organization are referred to as "targets" or "foci", and as Ashforth et al. (2008, p. 347) suggest, “a person may be a member of an occupation, department, task force, lunch group, and so on, each of which has its own, more or less distinct identity." Distinguishing amongst these foci of identification has yielded interesting findings with respect to a variety of important work-related attitudes, and there are recommendations for more research accounting for such circumstances (e.g., Ashforth et al., 2008). It is proposed here that the team sport environment offers a rich opportunity to dissect the construct of identification for the purposes of empirically investigating the efficacy of team employees who are also fans of said team.

Despite the proliferation of this research in a variety of organizational settings, there has been little to no attention paid to identification in relation to sport organizations. While the concept of identification has indeed had a major presence in the sport management literature, it has almost exclusively been studied from the consumer perspective in the form of a fan's psychological connection to a team (e.g., Wann \& Branscombe, 1990). As first suggested by Todd and Kent (2009), it is thought that employees within sport may attach heightened levels of 
significance to their organizational membership, due in part to the prominence, popularity, and level of affect typically associated with sport teams. It is reasonable to suggest that individuals working for team sport organizations may also be fans of their respective teams, as previous research has identified sport fandom is a primary motive for pursuing a career within the sport industry (e.g., Todd \& Andrew, 2008). While the ubiquity of identification is well-established for individuals who are external to sport organizations, the absence of research on employees in this environment represents a gap in the literature in need of attention. In concert with the idea that employees have different points of identification within an organization, we test here the proposition that team sport employees are able to cognitively differentiate between the team and the overall organization. We know of no other research which has empirically measured the organizational and team identification levels of employees who work for sport teams. In the event that these two constructs are distinct, practical implications include consideration of how employees view both the team and overall organization, as these attitudes may separately influence important organizational outcomes such as satisfaction and commitment. With the important attitudinal outcomes associated with these constructs, and the potential for sport employees having heightened levels of significance attached to their organizational membership (Todd \& Kent, 2009), the current research makes an initial attempt at providing some depth of understanding to the role of identification for those employed by a professional sports team.

\section{Theoretical Background}

The most prevalent theoretical framework in organizational identification research stems from Tajfel \& Turner's (1986) work on social identity theory (Riketta, 2005). It was from this perspective that Ashforth and Mael (1989) proposed that organizational identification is a specific form of social identification (or group identification), where members define themselves 
in terms of the organization as a social category. For example, Ashforth and Mael (1989) argued that when employees identify with their respective organizations, they effectively become "psychologically intertwined with the fate of the group" (Ashforth \& Mael, 1989, p. 21). In turn, a positive relationship between organizational identification and a broad spectrum of organizationally relevant outcomes such as satisfaction, cooperation, and organizational citizenship behaviors has since been well established in the literature (Ashforth et al., 2008).

The concept of team identification (Wann, 1997; Wann \& Branscombe, 1990) refers to an individual's psychological connection with a specific sports team. This stream of research has also drawn considerably from the social identity perspective (e.g., Tajfel \& Turner, 1986; Turner, 1984), where identification is seen as the degree to which a group is important and relevant to an individual (Wann, 2006). While in this scenario the fan is not a member per se of the group (team), this approach is consistent with the social identity perspective which accounts for a psychological connection to a group without technically being a member (Wann, 2006). In this circumstance, identification goes beyond actual group membership with fans becoming symbolic members who are psychologically connected to the actions and fate of the team (Ashforth \& Mael, 1989; Wann, 2006). A considerable amount of research in the consumer behavior literature has incorporated the construct of team identification. For example, team identification has been shown to be positively related to many behavioral, cognitive, and affective outcomes such as attendance, knowledge of the team, and emotional responses to game outcomes (Wann, 2006).

\section{Organizational and Team Identification as Distinct Constructs}

Rather than a single indivisible unit, organizations are instead a network of groups; each of which may serve as a source of identification in and of themselves (Ashforth et al., 2008; Ashforth \& Johnson, 2001). The most prevalent conceptualization of multiple identification foci 
is the hierarchical approach advanced by Ashforth and colleagues (Ashforth et al., 2008;

Ashforth \& Johnson, 2001), where formal membership categories are fully nested one inside the other (e.g., work group, department, organization). Whilst far less researched, Ashforth and Johnson (2001, p.41) maintain that "cross-cutting" (non-hierarchical) social categories also exist with either formal (e.g., cross-department committees) or informal membership (e.g., friendship groups). In the case of classifying team identification amongst sport team employees, this traditional approach does not provide clear guidance. That is, while the actual sports team is nested in the organizational structure, the traditional employee in this setting is not a formal member of this group (i.e., accountants do not physically participate in team competition).

A visual representation of the present scenario is provided in Figure 1. Each oval indicates a target of identification, with arrows representing employee attachment with various groups within the present organizational context. The left side of the model shows the traditional fully-nested approach, where individuals can identify with each hierarchical group in which they are formal members (i.e., work group, department, etc.). However, the right side of the model shows how employees may also identify with an organizational subunit of which they are not technically a member. Indeed, this is consistent with the social identity theory concept of a psychological group (Turner, 1984), where an individual does not have to be an actual member to identify with a group, but instead can do so on the basis of fandom or symbolic membership (Ashforth \& Mael, 1989; Mael \& Ashforth, 1992). As such, employee identification with the sports team is therefore referred to here as cross-nested in form. This terminology is used on the basis that it cuts across the organizational hierarchy of formal membership (Ashforth \& Johnson, 2001), yet is based on the psychological connection with a separately nested organizational 
entity. In addition, employees in this setting may subconsciously consider themselves as affiliate members of the sports team on the basis of existing within the same organizational structure.

\section{--- INSERT FIGURE 1 ABOUT HERE ---}

Another conceptual distinction relates to their respective theoretical underpinnings. Whereas organizational identification stems directly from social identity theory (Ashforth \& Mael, 1989), the concept of team identification originated from slightly different perspectives. For example, while team identification has more recently been influenced by social identity theory (Wann, 2006), its original conception was more specifically related to spectator "affective involvement" and "allegiance" (Wann \& Branscombe, 1990, p. 105). In contrast, organizational identification has been traditionally considered a "perceptual cognitive construct" not necessarily incorporating any affective elements (Ashforth \& Mael, 1989; Mael \& Ashforth, 1992). This distinction can also be seen in the construct definitions, which have consistently been referred to as a "perception of oneness" (Ashforth \& Mael, 1992, p. 104) with the organization, versus the extent to which one "feels psychologically connected" to the team (Wann, 1997, p. 331) (italics added for emphasis). Therefore, when comparing these two constructs, it appears that a larger emphasis on emotion exists within the concept of team identification. In summary, team identification is proposed to be a distinct construct from organizational identification in this setting, due to having a different focus of identification, employees' non-formal membership with the group, and its increased emphasis on the emotional connection with this collective.

Hypothesis 1: Team identification is a distinct construct from organizational identification for employees in professional sport organizations. 


\section{Development of the Conceptual Model}

While sport team identification has thus far only been studied from the perspective of the consumer, this research assesses the role it plays from the mindset of employees. In this sense, the conceptual model for the current study represents the confluence of these two constructs as they exist simultaneously in the context of team sport organizations. In developing the conceptual model (Figure 2), guidance was taken from the organizational identification literature, along with specific theoretical perspectives proposed by Ashforth et al. (2008) and Todd and Kent (2009). With no previous literature measuring team identification levels of organizational members, the organizational identification paradigm was used as the basic foundation for studying workplace attitudes in the context of sport. As such, the conceptually distinct construct of team identification was infused into the model for the first simultaneous assessment of these targets in the organizational context.

Following Griepentrog, Harold, Holtz, Klimoski, and Marsh (2012), the three antecedents chosen for the current study were prestige, distinctiveness, and perceived fit. As the authors note, these constructs are representative of three of the main principles of social identity theory, where attitudes toward a social entity depend upon the ability to enhance one's own self-concept (through prestige), the group's distinctiveness from comparable social categories, and the congruence of values and skills (perceived fit). The theoretical perspective advanced by Todd and Kent (2009) suggests that prestige and perceived fit are important antecedents for employee identity research in the context of sport. In addition, these antecedents also allowed for the assessment of both top-down (prestige and distinctiveness) and bottom-up (perceived fit) antecedents as posited by the model proposed by Ashforth et al. (2008). Following the approach by Edwards and Peccei (2010), these constructs were utilized for both organizational and team 
identification with their respective focus (e.g., 'organizational' prestige and 'team' prestige). In selecting appropriate outcomes of identification for employees in the sport context, guidance was taken from Todd and Kent's (2009) conceptual model, which resulted in the inclusion of organizational commitment, job satisfaction, and job involvement. These constructs were supported by their presence in Riketta's (2005) meta-analysis on organizational identification. Additionally, following Van Knippenberg and Van Schie (2000), work motivation was included in the model due to its frequent reference as an outcome of identification in the literature.

\section{--- INSERT FIGURE 2 ABOUT HERE ---}

\section{Antecedents of Identification}

Prestige. The concept of prestige refers to the extent an entity is well-regarded both in comparative and absolute terms (Ashforth \& Mael, 1992). Ashforth and Mael (1989) proposed that prestige would positively affect identification in the organizational context due to selfesteem boosts which occur through intergroup comparison. In the sports environment, a variety of organization-focused recognition categories exist which would be expected to positively impact employee levels of identification. For example, corporate social responsibility initiatives have become commonplace for professional sport organizations and are an area of increasing significance (Walker \& Kent, 2009). As some of the benefits from these prosocial initiatives are positive attitudes toward the organization (Lacey, Close, \& Finney, 2010) and an enhanced company image (Skudiene \& Auruskeviciene, 2006), it follows that these highly regarded attributes are more likely to be incorporated into an employee's self-concept (Dutton, Dukerich, \& Harquail, 1994). In addition to recognition for running these initiatives, various awards have also emerged to acknowledge successful programs and encourage engagement in prosocial behavior (e.g., Beyond Sport, 2013). As these initiatives and associated accolades tend to make 
the organization more highly regarded, it follows that employees may be more likely to define themselves in terms of the organization (Mael \& Ashforth, 1992).

Hypothesis 2a: Organization-focused prestige will be positively related to organizational identification for employees in professional sport organizations.

With regard to team-focused prestige, the sporting environment provides a number of ways in which teams are considered highly-regarded; the most notable being team success.

Criteria such as win-loss records and positions in the standings are readily available for employees to access from a whole host of platforms. As individuals often cognitively identify with a winner (Ashforth \& Mael, 1989), and as team performance has previously been seen to predict team identification amongst fans (e.g., Fisher \& Wakefield, 1998), it seems that team success will also be positively related to employee identification with the team. In their summary of the evolution of prestige, Henrich and Gil-White (2001) outline how prestige is related to the command something holds in people's minds and the degree of recognition and influence it has. As athletes are perhaps only equaled on these criteria by politicians and entertainment celebrities, sports teams provide several prestigious elements for consideration.

Hypothesis 2b: Team-focused prestige will be positively related to team identification for employees in professional sport organizations.

Distinctiveness. Organizational distinctiveness refers to the degree to which an organization has distinguishing characteristics that set it apart from other comparable entities (Mael \& Ashforth, 1992). As individuals look to accentuate their own distinctive characteristics, organizational distinctiveness provides a more salient definition for members to draw upon, and increases the likelihood of self-definition in organizational terms (e.g., Griepentrog et al., 2012). Organization-focused distinctiveness in professional sport organizations can be demonstrated through a "unique and compelling mission." (Mael \& Ashforth, 1992, p. 117). Beyond 
supporting the sport team's success, organizations also stress a variety of other more distinct elements such as providing superior entertainment value and helping sponsors grow their brands. By way of their philanthropic or charitable arms, many professional sport organizations have also elaborated on their missions to include an emphasis on various causes such as youth development and health and wellness (e.g., Anaheim Ducks, 2014). Sport organizations can also be seen as distinct through identifying symbols and "compelling images" (Ashforth \& Mael, 1989, p. 28), such as emblems, logos, and their brand identity (e.g., Tsiotsou, 2012). The unique characteristics of sport brands in particular, such as experiential, symbolic, hedonic properties, are considered likely to influence perceptions and evaluations (Tsiotsou, 2012). As sports employees are likely to be aware of the organization's mission and brand identity through internal communication and general awareness, it is likely that the degree to which they viewed as distinctive will be predictive of identification with the organization as a whole.

\section{Hypothesis 3a: Organization-focused distinctiveness will be positively related to} organizational identification for employees in professional sport organizations.

With regard to team-focused distinctiveness, the high level of transparency and competitive action in professional sports provides numerous ways teams can be viewed as distinct. In line with the social identity perspective on group evaluation (Tajfel \& Turner, 1986), head-to-head competition in the sport context provides one of the purest forms of social comparison. In essence, psychological group membership is "a matter of collective self-construal of - 'we' and 'us' versus 'them'” (Hogg, 2006, p. 115), and one answer to the question 'who's better?' is decided regularly and unambiguously on the field of play. Specific metrics available for team comparison lie in the vast number of statistics available in the sport context (e.g., home 
runs, touchdowns, rankings, etc.), and in other more general distinctions such as being 'tough' or having 'good chemistry'.

Hypothesis 3b: Team-focused distinctiveness will be positively related to team identification for employees in professional sport organizations.

Perceived fit. Perceived fit refers to the perceived match between the values and norms of an organization and those of an employee (Chatman, 1989). The main argument for perceived fit influencing identification is that individuals who recognize good fit will be more likely to also at least partially define themselves in terms of the organization (Cable \& De Rue, 2002). Organizational missions and prosocial activities may also serve as poignant signals which sport employees can utilize to assess value similarity. With the concepts of goals and culture often referred to in the realm of sport, it may be that these elements are more salient within this organizational context. Todd and Kent (2009) additionally suggest that perceived fit may be a contributing factor to why sport employees experience positive levels of identification exceeding that which is found in other industries.

Hypothesis 4a: Perceived fit with the organization will be positively related to organizational identification for employees in professional sport organizations.

A variety of sport-related characteristics can also be assessed with regard to perceived fit with the sports team. As one element of perceived congruence involves a personality factor (e.g., Kristof, 1996), sports teams themselves can also have perceived personalities. Examples include the 'blue-collar' Cincinnati Reds in the mid-1990's known for their hard work (Fisher, 1998), and the Detroit Piston's 'Bad Boys' of the late 1980's and 1990's known for their intensity and rough play (Heck, 2009). Furthermore, as a sports team's perceived culture (e.g., camaraderie and locker-room environment) is often taken into account by the sports media, fit with the groups culture (e.g., Kristof, 1996) can also be considered in assessing one's congruence with the team. 
Finally, perceived fit with the individual players in relation to attitude and geographic similarity may also be predictive of identification with the team (Fisher, 1998). These perspectives suggest that employees will be able to make evaluations of their fit with the team, and it is proposed that these perceptions could lead to a deeper psychological connection with this group of players.

Hypothesis 4b: Perceived fit with the team will be positively related to team identification for employees in professional sport organizations.

\section{Outcomes of Organizational Identification}

Affective commitment. Affective commitment refers to "an individual's emotional attachment to and engagement in an employing organization" (Bedeian, 2007, p. 13). The main rationale for this influence is that organizational identification is primarily a cognitive evaluation which has one of its most direct emotional expressions in commitment (Ashforth \& Mael, 1989; Mael \& Ashforth, 2001). Empirical evidence of this relationship has been demonstrated in a variety of organizational settings, including universities (Bedeian, 2007) and hospitals and engineering firms (Marique \& Stinglhamber, 2011).

Hypothesis 5a: Organizational identification will be positively related to affective organizational commitment for employees in professional team sport organizations.

Job satisfaction. Job satisfaction is defined as "a positive (or negative) evaluative judgment one makes about one's job or job situation" (Weiss, 2002, p. 175). The literature indicates job satisfaction to be one of organizational identification's pertinent outcomes (Ashforth et al., 2008), with a consistent positive association demonstrated between the two constructs (Riketta, 2005). One basis for this relationship is that identified employees would likely "enjoy a sense of consonance" which would then positively influence their satisfaction with their job (Efraty \& Wolfe, 1988, p. 106). This view is also in line with Todd and Kent's (2009) proposition that the psychological fulfillment and identity development experienced 
through membership in the sport context may indeed contribute to increased levels of job satisfaction.

Hypothesis 6a: Organizational identification will be positively related to job satisfaction for employees in professional team sport organizations.

Job involvement. Job involvement refers to the degree of cognitive preoccupation and concern an employee has with their current job (Paullay, Alliger, \& Stone-Romero, 1994). The basic premise of this relationship is that as individuals self-define in terms of the organization, their job within this context will also become "part of the self" and lead to increased mindfulness in their work (Van Knippenberg \& Van Schie, 2000, p. 141). In addition, with the elevated importance placed on focus and concentration in the team sport context, such characteristics may also be viewed as key aspects of team sport organizations. As employees define themselves more in terms of their organization, such an emphasis might also translate to an increased focus and preoccupation with one's job.

Hypothesis 7a: Organizational identification will be positively related to job involvement for employees in professional team sport organizations.

Work motivation. Work motivation is defined as "the desire to expend effort based on the interest in and enjoyment of the work itself" (Grant, 2008, p. 49), and the literature provides support for this construct as an outcome of organizational identification (Ashforth et al., 2008; Van Knippenberg \& Van Schie, 2000). The basic argument is that as identification aligns the interests and behaviors of individuals with their organizations, motivation increases due to effort on behalf of the organization being viewed as effort on behalf of the employee (Dutton et al., 1994; Van Knippenberg \& Van Schie, 2000). Furthermore, as elevated importance may be placed on effort in the sport context, this concept may be more salient and available for incorporation into one's self-concept. 
Hypothesis 8a: Organizational identification will be positively related to work motivation for employees in professional team sport organizations.

\section{Organizational Outcomes of Team Identification}

As noted in the introduction, no known empirical research exists which measures sports team identification and its relative effects inside the boundaries of organizational structure. In such circumstances, it seems appropriate to consider one of the most fundamental aspects of fandom; that individuals want their teams to be successful. This general concept has been demonstrated in the literature in the following ways. First, it is well-established that highly identified individuals experience more intense responses to game outcomes than others (Wann, 2006). For example, Wann, Dolan, McGeorge, and Allison (1994) found highly identified fans to have higher increases in emotions (e.g., happiness and anger) after both wins and losses as compared to those low in team identification. Second, highly identified fans are more likely to take action in an attempt to help the team (Wann, 2006). For example, previous research indicates that highly identified fans are more likely to be verbally aggressive towards officials and opposing fans, and more willing to consider actions such as cheating and inflicting harm on opposing players or coaches to benefit team performance (Wann, 2006). In addition, previous research has also indicated that the more identified an individual is with a team, the more influence they perceive that fans can have on game outcomes (Wann et al., 1994). Taken together, it is clear that team performance matters a great deal to fans.

The current research proposes that employees working inside the organization who are psychological attached to the sports team will have a similar mindset as individuals who are external to the organization. That is, team success will take on elevated importance and they will be more willing to act on behalf of the team. Additionally, it is proposed that these individuals 
will view their job situation as a special opportunity to contribute to team success in a more formal way. In this sense, individuals will consider themselves as more 'instrumental' in the process, because their actions more directly contribute to their team's performance (e.g., Wann, Carlson, \& Schrader, 1999). Additionally, perceiving themselves as having 'insider status' (e.g., Stamper \& Masterson, 2002) should lead to a special sense of responsibility, due to being able to make more of a difference than fans outside the organization. In essence, being an employee of the sport organization will 'matter' more for individuals who identify with the team. Therefore, it seems reasonable that such circumstances will lead to employees having positive attitudes toward their job, and the organization providing the structure for these positions to exist.

In relation to the current study, the construct of affective commitment in effect represents the desire to pursue actions relevant to that organization (Todd \& Kent, 2009). As the primary objective of professional sport organizations is generally to produce team success, such a goal is in line with the aspirations of individuals who identify with the team. That is, the more highly identified the employee is with the team, the more likely they will desire outcomes which are relevant to the core objective of the organization. With regard to attitudes toward one's position, the perception that one's job 'matters' equates to a sense of meaningfulness in the work environment (Sluss, Ashforth, \& Gibson, 2012). In turn, this perceived meaningfulness in organizational life is generally associated with a variety of positive workplace outcomes stemming from the personal positive enrichment gained in such a setting (Hackman \& Oldham, 1980). A similar position is suggested with regard to job involvement, as jobs are more likely to be considered to have personal relevance and importance when they are also deemed as meaningful (Lambert, 1991). In summary, because employees who identify with the team will 
find more meaningfulness in their jobs and desire similar results as their employer, it is proposed that team identification will be positively related to these organizational outcomes.

Hypothesis 5b-8b: Team identification will be positively related to affective organizational commitment, job satisfaction, job involvement, and work motivation for employees in professional team sport organizations.

\section{Methodology}

\section{Sample and Measures}

The participants for the current study were business operations employees from 107 randomly sampled organizations from Major League Baseball (MLB, 23), Major League Soccer (MLS, 14), the National Basketball Association (NBA, 23), the National Football League (NFL, 24), and the National Hockey League (NHL, 23). The participants in this study worked in departments with names such as accounting, finance, marketing, communications, public relations, sales, facilities, human resources, information technology. The data were collected via online surveys sent to 10,308 employees, via a proportional stratified sampling method (Leedy \& Ormrod, 2001) where $75 \%$ of the teams in each league were randomly chosen to be surveyed.

Five organizations from one particular sports market were excluded due to their participation in a concurrent research project. A total of 1,189 participants who indicated that "business operations" (as opposed to "team" operations) was where their job resided completed the survey for a response rate of $11.5 \%$. The participants were $66.9 \%$ male, $84.7 \%$ Caucasian, and had an average age of 36.0 years old. The average organizational tenure was 5.6 years, with $83.3 \%$ of respondents being employed by their current organization for 10 years or less. With regard to league representation, 34\% of the sample was from MLB, $22.3 \%$ from the NHL, $19.6 \%$ from the NBA, $18.3 \%$ from the NFL, and 5.8\% from MLS. 
This study used survey items which have been used extensively in the relevant literature and have been shown to be valid and reliable. Each scale used five-point Likert-type scales unless otherwise indicated ( $1=$ strongly disagree and $5=$ strongly agree). The antecedents (both organization and team-focused) were measured with items from the scales listed below. For the team-focused constructs, 'team' was utilized in place of 'organization.' As an example prestige item, "my organization is considered one of the best" was modified to "the team is considered one of the best" for the team-focused construct. Prestige was measured with Mael and Ashforth's (1992) six-item scale, with team-focused prestige being measured with four items from the same scale, as two items were not deemed appropriate with respect to the word substitutions necessary for changing foci. The Distinctiveness measure was adapted from the 4items used by Griepentrog et al. (2012), who found this scale to indicate adequate reliability ( $\alpha=$ .75) and also demonstrate a positive relationship with group identification. Perceived fit was measured with the 3-item measure developed by Cable and DeRue (2002), which is one of the most common fit measures and generally indicates high reliability scores (Kristof-Brown \& Guay, 2011). Each item was measured on a 7-point Likert-type scale. Organizational identification was measured with the original scale developed by Mael and Ashforth (1992), which meta-analytic research has referred to as the best measure available (Riketta, 2005). Team identification was assessed with the seven-item Sport Spectator Identification Scale (SSIS) (Wann \& Branscombe, 1993), which was the original scale developed to measure team identification. This measure of team identification has been used extensively in the literature and has been shown to be valid and reliable (Madrigal, 2000; Wann, 2006). For the current context of sports employees, two items were modified by substituting 'away from work' for the phrases 'during the season' and 'at your place of work.' Each item was measured with the original 
anchors on an eight-point Likert-type scale. Affective commitment was measured using Meyer, Allen, and Smith's (1993) six-item affective commitment scale which commonly used in the literature. To measure job satisfaction, Cammann et al.'s (1983) three-item scale was used, and job involvement was assessed using the five-item abbreviated version of Kanungo's (1982) job involvement scale as utilized by Frone, Russell, and Cooper (1995). Each item was measured on a 6-point Likert-type scale. Finally, work motivation was assessed with Grant's (2008) four-item scale, which has seen reported reliability levels of greater than .90 consistently (e.g., Grant, 2008). Each of these items were measured on a 7-point Likert-type scale.

\section{Data Analysis and Results}

Non-Response and common methods. Non-response error is concerned with differences between respondents and non-respondents, and whether respondents can be seen as true representatives of the entire sample (Dillman, Smyth, \& Christian, 2009; Jordan, Walker, Kent, $\&$ Inoue, 2011). In order to assess the potential for non-response error, a short survey was sent to approximately 3,000 non-participants from the original list of employees. The survey included two demographic variables (age and gender), and one item from for four different constructs in the study. The 104 respondents to the survey were then compared to original survey respondents. First, the results of a chi-square test $(\mathrm{p}=.49)$ indicated that responders and non-responders did not differ with respect to gender. Second, a MANOVA indicated no overall difference between responders and non-responders with regard to the other five included variables $\left(\right.$ Wilks $^{\prime} \Lambda=.99$, $F(5,1287)=1.82, \mathrm{p}=.11)$

Common method bias refers to an aspect of measurement error that it attributable to the method used in a particular study (Podsakoff, MacKenzie, Lee, \& Podsakoff, 2003). Harman's one-factor test was conducted by performing a principle component analysis with all items in the 
study (e.g., Stam \& Elfring, 2008). Thirteen distinct factors were extracted explaining $67 \%$ of the total variance, with the first factor accounting for $21 \%$. With no single factor emerging, nor one which accounted for a majority of the variance explained, these results lessen the concern for common method variance in the current research (Stam \& Elfring, 2008). As a second test, a single item marker variable (agreeableness) was included as marker variables are theoretically not related to any of the other variables (Podsakoff et al., 2003). Other than a small positive association with affective commitment (.08) and job satisfaction (.12), the marker variable was not significantly correlated with any of the other constructs in the study $(\mathrm{p}<.05)$.

Analysis Part I: Assessing Discriminant Validity for Identification Constructs. In relation to the first hypothesis, discriminant validity refers to "the degree to which two conceptually similar constructs are distinct" (Hair et al., 2006, p. 137). To assess the discriminant validity of organizational and team identification, a series of four statistical analyses were conducted. First, the correlation level between the two focal constructs was considered, and then also compared with other identification relationships in the literature. The bivariate correlations and internal-consistency reliabilities for the individual scales are provided in Table 1, with internal consistency reliability values for all constructs being above the .70 level. The correlation between organizational and team identification was of moderate size (.33) and lower than other bivariate correlations between organizational identification and foci such as: work group identification (.41) (Van Knippenberg \& Van Schie, 2000), work team identification (.49) (Wieseke, Kraus, Ahearne, \& Mikolon, 2012), department identification (.34) and business unit identification (.53) (Bartels, Pruyn, de Jong, \& Joustra, 2007), occupational identification (.52) (Marique \& Stinglhamber, 2011), and identification with a parent organization (.55) (Edwards \& 
Peccei, 2010). In comparison to these relationships, the correlation level in the current study indicates relatively robust discriminant validity between constructs.

--- INSERT TABLE 1 ABOUT HERE ---

Second, following Govindarajan and Kopalle (2006), an exploratory factor analysis was performed with the combined items of the identification scales. This provided an indication of whether the items represented two different factors rather than one all-inclusive identification construct, as well as an assessment of the individual loadings and cross-loadings across factors. A direct oblimin (oblique) rotation was utilized on the basis that the extracted factors would be expected to correlate (Hair et al., 2006). With two factors emerging that had eigenvalues greater than one, this provided support for both discriminant validity and the unidimensionality of constructs (Govindarajan \& Kopalle, 2006). Additionally, the results supported the expected pattern of the items, with all loadings being significant $(\mathrm{p}<.05)$, all cross-less than .10, and only one item (TID6) loading was below the .50 level.

Third, a confirmatory factor analysis (CFA) was conducted where both sets of items were first specified to load on their respective factor. Table 2 shows that each item significantly loaded onto its respective factor in the original CFA, however the sixth item for team identification (TID6) was lower that the recommended threshold of .5 (Hair et al., 2006, Hulland, 1999). As items may sometimes load inappropriately due to an improper transfer to a certain context (Hulland, 1999), further analysis was taken with regard to this item which read, "How much do YOU dislike the team's greatest rivals?" Previous research has indicated that this item (which speaks to an aversion of rival sports fans) does not perform like the other items in situations where inter-group animosity is not prevalent (Bodet \& Bernache-Assollant, 2011). For employees working in professional sport, it is likely that participants in the current study would 
have a differing perspective on rival fans than individuals working outside of the industry. That is, it seems that many sports employees would see rival sports fans as an essential component of their environment, and therefore not view them in the same way as non-sports employees. Therefore, this item was excluded from further analysis due its loading being clearly below the .5 level (Hair et al., 2006, Hulland, 1999), its potentially inappropriate transfer to the present context (Bodet \& Bernache-Assollant, 2011), and its exclusion in other studies (e.g., Madrigal, 2000; Walker \& Kent, 2009). The results of the revised CFA excluding TID6 are also shown in Table 2, with all of the items loading above the .5 level. With the exception of the chi-square to degree of freedom ratio, the revised model generally indicated having good fit with the data $(\chi 2 / d f=238 / 53=4.5, \mathrm{CFI}=.95, \mathrm{RMSEA}=.05, \mathrm{SRMR}=.04)$, and was therefore retained for comparison in further analysis. The next stage of the analysis compared the preceding two-factor model to one which constrained the relationship between organizational identification and team identification to be equal to one (Anderson \& Gerbing, 1988). Constraining the relationship between the latent factors equal to one indicated significantly worse fit with the data than the unconstrained model $\left(\Delta \chi 2_{(I)}=785, \mathrm{p}<.001 ; \chi 2 / d f=1426 / 54=26.4, \mathrm{CFI}=.66, \mathrm{RMSEA}=.15\right.$, SRMR $=.14$ ), providing additional support for discriminant validity (Anderson \& Gerbing, 1988). As appropriate with MLR estimation, the Satorra-Bentler scaled chi-square difference test was used for all SEM analysis (Muthén \& Muthén, 1998-2012).

\section{--- INSERT TABLE 2 ABOUT HERE ---}

The final assessment of discriminant validity utilized the CFA procedure to compare the AVE values to the squared interconstruct correlation (SIC) between the identification constructs (Fornell \& Larcker, 1981; Hair et al., 2006). This assessment is based on the premise that each latent construct should explain less variance in another latent construct than it does with its own 
items. The AVE values were .42 for organizational identification and .53 for team identification. It should be noted that the AVE value for organizational identification is below Fornell and Larcker's (1981) recommendation of .5 as an indication of convergent validity. However, because this is a more conservative measure and AVE values are often below .5 (Jiang, Klein, \& Carr, 2002), convergent validity may be evaluated on the basis of construct reliability (CR) alone (Fornell \& Larcker, 1981). The CR values for both organizational identification (.81) and team identification (.87) both well above the recommended level of .7, indicating an adequate level of convergent validity. In addition, it is worth noting that one of the foundational studies for this measure of organizational identification had an AVE value of .43 (Mael \& Tetrick, 1992), and AVE values below .5 are not uncommon in the literature (e.g., Govindarajan \& Kopalle, 2006; Jiang et al., 2002). In relation to the current assessment of discriminant validity, the SIC value of $.15(r=.38)$ between the identification constructs was still well below both AVE values for both factors, providing additional support. Finally, the correlation level of .38 provides additional support, as discriminant validity is generally not viewed as a concern for correlations unless they exceed the .85 level (Kline, 2005). In the aggregate, the results of the preceding analyses provide strong support for the discriminant validity of organizational and team identification.

Analysis Part II: Structural Equation Modeling. The measurement model for the current study was assessed by conducting a confirmatory factor analysis (CFA) using the Mplus 7.1 statistical analysis program. This model specified 12 latent constructs using 54 items, and satisfied the 5:1 response-to-parameter guideline as recommended in the literature (Bentler \& Chou, 1987; Kline, 2005). As some of the items had non-normal distributions, maximum likelihood estimation with robust standard errors (MLR) was used for all SEM analysis, which addresses the potential violation of multivariate normality in such circumstances (Muthén \& 
Muthén, 1998-2012). The CFA for the original measurement model indicated acceptable fit with the data $(\chi 2 / d f=3776 / 1311=2.9, \mathrm{CFI}=.93, \mathrm{RMSEA}=.04, \mathrm{SRMR}=.05)$. Due to the antecedents utilizing the identical items with only key words changed with regard to the relevant foci, an additional model was assessed which allowed the error terms for the corresponding items to correlate (e.g., Rich et al., 2010). The model with the correlated error terms indicated a significantly better fit with the data $\left(\Delta \chi 2_{(11)}=271, \mathrm{p}<.001 ; \chi 2 / d f=3417 / 1300=2.6, \mathrm{CFI}=.94\right.$, RMSEA $=.04$, SRMR $=.05)$ and was therefore retained for further analysis. All factor loadings were significant and above the recommend .5 level (Hair et al., 2006, Hulland, 1999).

The measurement model was further assessed with regard to reliability estimates and AVE values as recommended by Fornell and Larcker (1981). All construct reliability (CR) values exceeded .7, and all AVE values were deemed acceptable for the current analysis (Jiang et al., 2002). As previously outlined, AVE values were also used to assess the discriminant validity of all of the constructs in the analysis. In all but the following three cases, the AVE was greater than the SIC values between relevant constructs pairs: organizational prestige and team prestige; organizational fit and affective commitment; and, affective commitment and job satisfaction. Chi-square difference tests were then conducted comparing the measurement model to three alternate models which constrained the relationship between these construct pairs to 1.0 (Anderson \& Gerbing, 1988). The results of these analyses indicated that the constrained model in all three cases had worse fit with the data than the unconstrained measurement model: organizational prestige and team prestige $\left(\Delta \chi 2_{(I)}=258, \mathrm{p}<.001\right)$; organizational fit and affective commitment $\left(\Delta \chi 2_{(1)}=159, \mathrm{p}<.001\right)$; and affective commitment and job satisfaction $\left(\Delta \chi 2_{(1)}=\right.$ $105, \mathrm{p}<.001)$. These results lessened the concern for discriminant validity issues between these constructs, and the measurement model was therefore retained for use in the structural model. 
The structural model was assessed while including four control variables throughout the entire model. First, both age and organizational tenure were included due to their positive relationship with organizational identification as seen over a variety of studies (Riketta, 2005). Gender was also controlled for due to previous research indicating that males can display higher levels of team identification than females (e.g., Wann, Haynes, McLean, \& Pullen, 2003). Finally, due to the possibility that employees may identify more with their respective sports teams during their respective seasons, a dummy variable for this element (In-season 1; Offseason 0) was also included.. The structural model indicated acceptable fit with the data $\left(\chi^{2 / d f=}\right.$ $4490 / 1523=2.9, \mathrm{CFI}=.92, \mathrm{RMSEA}=.04, \mathrm{SRMR}=.07)$.

After determining acceptable fit for the hypothesized model (Model 1), three different hierarchically-related models were considered. Following Griepentrog et al. (2012), the first analysis assessed whether including the concept of team identification (Model 1) provided a better fitting model than one without (Model 2). Model 2 was specified as a nested model with the effects of team identification and its antecedents constrained to be zero (Griepentrog et al., 2012). The results of this constrained model indicated significantly worse fit with the data $\left(\Delta \chi 2_{(11)}=481, \mathrm{p}<.001\right)$ as compared to the unconstrained model. The next hierarchical model tested the presence of cross-foci effects by the antecedents on the identification constructs (e.g., Edwards \& Peccei, 2010; Holtz \& Harold, 2009; Lavelle, Rupp, \& Brockner, 2007). While the antecedents were expected to demonstrate target similarity and be positively associated with their like-foci identification construct, spillover effects (Lavelle et al., 2007) may also exist between each identification construct and their cross-foci antecedents. In the current study, plausible examples include effects such as team distinctiveness positively influencing organizational identification, and perceived fit with the organization having a positive effect on team 
identification. To test this possibility, Model 3 consisted of six additional paths which specified relationships between the organization-focused antecedents and team identification, as well as between the team-focused antecedents and organizational identification. Results from the chisquare difference test indicated that Model 3 had significantly better fit $\left(\Delta \chi^{2}{ }_{(\sigma)}=43, \mathrm{p}<.001\right)$ than Model 1, and Model 3 was therefore retained as the better representation of the interrelationships between the constructs.

As Model 3 had six non-significant paths from the antecedents to the identification constructs, a fourth model was tested which constrained these non-significant paths to be zero (Model 4). As this model indicated no significant difference in fit $\left(\Delta \chi^{2}(6)=9\right.$, ns) with Model 3, Model 4 was retained as the final model (see Figure 3) due to being more parsimonious while not sacrificing model fit (e.g., Holtz \& Harold, 2008). The constrained paths included both the likefoci and cross-foci effects of organizational and team prestige, as well as the cross-foci effects of organizational and team distinctiveness. The standardized results of the final structural model are listed in Table 3. While Hypotheses $2 \mathrm{a}$ and $2 \mathrm{~b}$ were not supported due to organizational and team prestige not displaying any significant effects in Model 3, all of the remaining hypotheses were supported.

\section{--- INSERT FIGURE 3 and TABLE 3 ABOUT HERE ---}

Independent effect of team identification. As a means of further assessing the effect of team identification on the outcomes, the two following analyses were conducted. First, a series of models were compared against the final structural model (Model 4) which constrained to zero the individual path from team identification to each of the outcomes. In each case, the alternate model had significantly worse fit with the data: affective commitment $\left(\Delta \chi 2_{(1)}=847, \mathrm{p}<.001\right)$; job satisfaction $\left(\Delta \chi 2_{(I)}=49, \mathrm{p}<.001\right)$; job involvement $\left(\Delta \chi 2_{(I)}=57, \mathrm{p}<.001\right)$; and work 
motivation $\left(\Delta \chi 2_{(l)}=31, \mathrm{p}<.001\right)$. In addition, following Schaubroeck, Lam, and Peng (2011), hierarchical multiple regression analysis was conducted to assess the significance of team identification's contribution to the explained variance of each outcome. For each outcome, the control variables and organizational identification were first entered as predictors. Next, the magnitude and significance of the R-square change was assessed for each of the four dependent outcomes. In each case, adding team identification resulted in a significant difference in the explained variance of each outcome: affective commitment $\left(\Delta R^{2}=.12, \mathrm{p}<.001\right)$; job satisfaction $\left(\Delta R^{2}=.05, \mathrm{p}<.001\right) ;$ job involvement $\left(\Delta R^{2}=.07, \mathrm{p}<.001\right) ;$ and work motivation $\left(\Delta R^{2}=.04, \mathrm{p}<\right.$ .001). Collectively, these results indicate that team identification independently predicts all of the attitudinal outcomes, and explains an additional 4-12\% of the variance in each construct.

\section{Discussion}

This study sought to investigate the role of identification for employees within professional sports organizations. To this end, the first aim was to determine if team identification was a distinct construct from organizational identification. The collective results of a variety of discriminant validity assessments provide strong support for this proposition. This suggests that dual identification exists in the context of professional sport, as employees simultaneously and distinctly identify with the overall organization and the affiliated sports team. While the current context is slightly different due to sport employees not being formal members of each focal entity, the concept of dual organizational identification (DOI) proposed by Vora and Kostova (2007) is one worthy of consideration. Although herein we provide no specific guidance for determining the form of dual identification, it may be that the relationship between organizational and team identification falls somewhere on a continuum between the distinct and compound categories within their framework. That is, while the analyses provided strong support 
for the constructs to be considered as separate concepts, it is possible that some degree of cognitive overlap might still exist between these two types of identification.

With regard to the hypothesized structural model, the results provide support for the notion that target-specific antecedents also play a role in the identification process. Specifically, organizational distinctiveness and fit each demonstrated a positive relationship with organizational identification. Likewise, team distinctiveness and fit also showed a positive relationship with team identification. Contrary to expectation, however, one of the most notable results was that neither organization-focused prestige nor team-focused prestige had a significant influence on their respective identification construct when controlling for distinctiveness, perceived fit, and the demographic variables. While a non-significant effect has been seen before with a relatively less prestigious organization such as an engineering firm (e.g., Marique, Stinglhamber, Desmette, Caesens, \& De Zanet, 2013), these results were not expected in the highly revered context of professional sports. Additionally, this finding is inconsistent with Todd \& Kent's (2009) proposition that prestige plays an important role in augmenting positive social identity for sport employees. However, as this argument was developed in relation to the attraction phase of the employment cycle, it could be that this phenomenon is most relevant prior to becoming an employee in sports organizations. As an alternate explanation, it is possible that the impact of prestige in this environment is not something which manifests at the organizational level, but has an influence at more of a macro level. That is, because prestige has a comparative component, it could be that this is based more on a comparison between industries than it is between sport organizations or teams.

The cross-foci effects indicated in the structural model results are also worthy of consideration. As an employee's perceived fit with both the organization and team had a positive influence on both identification constructs, this suggests that perceived fit takes on a more complex role in the professional sports setting. In addition, while cross-foci effects are generally 
expected to be weaker than those between constructs of the same focus (Lavelle et al., 2007), the results show these effects to be relatively similar in magnitude. This suggests that in addition to organizational fit having an impact on organizational identification, employees' perceived fit with the sports team also has a positive influence. That is, if employees perceive the team on the field to be similar to themselves, this in turn has a positive effect on their level of organizational identification. Likewise, beyond their perceived fit with the team, these results suggest that organizational fit will also positively affect their team identification level, so while team-specific elements play a role in this process, perceived congruence with organizational values and norms also has a positive influence on employee levels of team identification. In summary, these findings suggest employees in professional sports have perceptions of fit with both the organization and team, which in turn each play a role in their identification with both entities.

With regard to the outcomes, one of the overarching themes of this research is that team identification may play an independent role in relation to important workplace attitudes. In concert with more established theory on organizational identification, the structural equation modeling results provided additional support for its impact on the outcomes included in this study. However, the support found for Hypotheses 5b-8b provides the basis for a more significant contribution to the literature. That is, the results suggest that beyond the impact of organizational identification, team identification also has a significant influence on workplace attitudes in this setting. These results indicate that while accounting for employee identification with the organization as whole, their psychological connection with the team does indeed have an impact on how committed, satisfied, motivated, and cognitively involved they are in relation to their workplace environment. The practical implication for sport managers is that consideration should be made for how sports employees in this environment identify with the 
overall organization as well as the actual team. That is, both constructs play a role in influencing employee levels of commitment, satisfaction, motivation, and cognitive involvement. While the hierarchical regression results indicate the incremental effect of team identification to be between small (.02) and medium (.13) in size (Cohen, 1988), it should be noted that these outcomes are generally ones with more established relationships with organizational identification. That is, while the results support team identification's independent prediction of these outcomes, it is possible that this construct could have more pronounced effects on other workplace attitudes not included here. In addition, in relation to the relatively strong effect that organizational identification has been seen to have on affective commitment in the literature (e.g., Bedeian, 2007; Marique \& Stinglhamber, 2011), it is perhaps most notable that team identification had the largest incremental effect on affective commitment, explaining an additional $12 \%$ of the variance in the current study.

\section{Theoretical Perspectives}

A general theoretical contribution was made by introducing the concept of a sports team as an additional target of identification in the organizational context. As organizations are complex entities with multiple foci embedded within (Ashforth et al., 2008), the results indicate that the professional sports environment includes an additional target not present in other organizational contexts. This contribution was further developed by extending Ashforth and Johnson's (2001) framework to include cross-nested targets which are neither specifically hierarchical nor cross-cutting in nature. In relation to organizations outside of sport, the current situation could be compared to employees who are members of one department identifying with another. For example, as the team in a sport organization can be viewed as the component which provides the essential product, such a subunit could represent the technical core (Thompson, 
1967) or operating core (Mintzberg, 1979) of the company. Applying the cross-nested perspective to companies such as Apple or Microsoft would mean that beyond their work group and overall organization, employees may also identify with the computer engineer or research and design departments. Similar situations could also apply for other complex companies containing work groups that have elevated importance or status within the workplace setting.

A second contribution was made by distinguishing team identification as a distinct concept from organizational identification for employees working in the professional sport environment. While a conceptual distinction can be made between the two entities, the results of this study provided empirical evidence that identifying with the team represents a different concept than identifying with the overall organization. Since the concept of team identification has been measured exclusively with individuals outside of the organization, and without reference to organization-specific considerations, it is possible that this measure has previously captured elements of identifying with the organization as a whole. Therefore, in addition to considerations relating to managing employees, delineating the notion of organization versus team may also have implications for consumer behavior research. For example, while perhaps being in a less-informed position when compared to employees, it is possible that fans may also be able to cognitively distinguish between these concepts. In such an instance, it would follow that beyond the established effects of team identification, organizational identification may also be a significant predictor of important attitudes and behaviors relating specifically to consumers. Such a circumstance would be in line with corporate marketing perspectives which advocate for consideration of the various ways organizations are conceptualized by the general public (e.g., Balmer, 2009). 
A third contribution is made by introducing perceived fit with the team as an additional antecedent to organizational identification in this context. Whilst person-organization fit has previously demonstrated a positive relationship with organizational identification (e.g., Cable \& DeRue, 2002), the current research indicates that in the professional sports context employees' perceived fit with the team also plays a role. Additionally, such a situation could also exist with organizations outside of sport. For example, in a similar fashion as discussed above, this finding could mean that employees' identification with companies like Apple or Microsoft could in part be related to their perceived fit with a core sub-unit of the organization.

As a final contribution, this study provides some initial evidence regarding the relevance and appropriateness of being a fan in the workplace. In the face of conflicting anecdotes of whether fandom is a benefit or detriment for employees working in professional sport, the results of this study generally support the notion that identifying with the team leads to more positive workplace attitudes. While not necessarily the case for employees in every situation or department in professional sport, this study indicates that higher levels of psychological connection with the team is generally associated with employees being more committed, satisfied, motivated, and cognitively involved in their workplace environment.

\section{Future Research}

The cross-sectional design of the study does not allow for conclusions to be made regarding causality, nor does it account for the potential for time-specific circumstances to affect the data in a way which could be different at an alternate point in time. Future research should therefore look to collect data at different times of the year to address this issue. Additionally, the analyses of the measurement model and structural model were conducted using the same sample. While this is common practice in the literature, and the data had representation from all five 
major sports leagues in North America, cross-validation with different samples is recommended for future research. Future studies looking to build from this work should consider the potential for other sport-specific targets in this setting. For example, identification with a particular sport (e.g., Trail, Robinson, Dick, \& Gillentine, 2003), or the concept of sport in general, may also be factors related to workplace attitudes. That is, the degree to which people in this industry define themselves in relation to certain aspects of sport may also be related job attitudes such as satisfaction and cognitive involvement. Additionally, as brand identification for consumers has received attention in the literature (e.g., Kuenzel \& Vaux Halliday, 2008), future research should consider the role that employee identification with the company brand plays in relation to workplace attitudes. Another avenue for investigation may look to assess the relationship between team identification and other workplace attitudes and behaviors. For example, fandom has been associated with consumer outcomes such as self-esteem, anxiety, and aggressive behavior (Wann, 2006), and as such future research should consider if team identification might have a similar impact within the workplace.

Future research should also consider the potential for team identification to play a role in organizations which have a relationship with professional sports teams. For example, in premier league soccer throughout Europe, strong associations are developed between teams and their shirt sponsors (e.g., Manchester United and Vodafone). When two entities are constantly promoted in the marketplace together, it is possible that employees working for sponsoring organizations may also have a psychological connection with the associated sports team which influence other attitudes in the workplace environment. In addition, it may also be useful for non-sport organizations to promote such an affiliation in the interest of attracting quality employees (e.g., O’Neil, 2014) 
While the current results indicate positive employee outcomes associated with team identification, negative outcomes as a result of being a fan are also possible, such as decreased productivity and negative emotions in the face of losses. Therefore, in the interest of pursuing a balanced perspective of team identification in the workplace, less favorable outcomes should also be incorporated into future research endeavors. In concert with this idea, future research might also consider the effects of extreme levels of identification. In the way that overly satisfied employees may not necessarily be the most high-performing (Forbes, 2012), a certain threshold for team identification may exist which represents the beginning of diminishing returns. For example, employees may actually be more cognitively involved with their actual job, if they are not identified with the team at an extremely high level. Future research should therefore consider the potential for an optimal range of team identification levels which maximizes employee attitudes and, ultimately, performance.

Finally, while the terms team identification and fan identification have been used interchangeably in the consumer behavior literature (e.g., Dimmock \& Grove, 2005; Pritchard, Stinson, \& Patton, 2010), future research should consider the appropriateness intermixing this terminology. For example, using the multi-focus which is common in the organizational behavior literature (e.g., Ashforth et al., 2008), fan identification would represent the degree to which an individual identifies with fans, rather than the actual team. This loose exchange of the terminology indeed becomes problematic when considering how the management literature has labeled different identification constructs specifically by the name of the focal entity (e.g., work group and organization). When considering the interrelatedness of these two different groups (teams and fans), future research should consider identification with the actual team who competes on game night, as well as the group of individuals who support the team. That is, the 
concept of team identification as traditionally used in the literature, might be more appropriately differentiated between team identification and fan group identification.

In conclusion, this study provides empirical support for Todd and Kent's (2009) proposition that the sport industry contains areas of distinction in relation to employee psychology. Specifically, the results indicated that employees of professional sport organizations have dual targets of identification which exist simultaneously and independently predict key attitudinal outcomes in the workplace. Managers should therefore be aware of these targets and incorporate strategies for promoting optimal identification levels with regard to both entities. Consistent with Chalip's (2006) proposition that the sport environment can serve as a source for theory building, the theoretical development of the current study was based on phenomena grounded solely in the context of sport. As the fields of sport and business both endeavor to make strides in organizational performance, domain-specific considerations regarding employee attitudes may provide additional pathways to increased levels of productivity. 


\section{REFERENCES}

Anaheim Ducks (2013). The Anaheim Ducks Foundation. Retrieved August 15, 2014, from http:// http://ducks.nhl.com/club/page.htm?id=66275.

Anderson, J. C., \& Gerbing, D. W. (1988). Structural equation modeling in practice: A review and recommended two-step approach. Psychological Bulletin, 103(3), 411-423.

Ashforth, B. E., Harrison, S. H., \& Corley, K. G. (2008). Identification in organizations: An examination of four fundamental questions. Journal of Management, 34(3), 325-374.

Ashforth, B. E., \& Johnson, S. A. (2001). Which hat to wear? The relative salience of multiple identities in organizational contexts. In M. A. Hogg \& D. J. Terry (Eds.), Social identity processes in organizational contexts (pp. 31-48). Philadelphia, PA: Psychology Press.

Ashforth, B. E., \& Mael, F. (1989). Social identity theory and the organization. Academy of Management Review, 14(1), 20-39.

Bartels, J., Pruyn, A., de Jong, M., \& Joustra, I. (2007). Multiple organizational identification levels and the impact of perceived external prestige and communication climate. Journal of Organizational Behavior, 28(2), 173-190.

Bedeian, A. G. (2007). Even if the tower is "ivory," it isn't "white:" Understanding the consequences of faculty cynicism. Academy of Management Learning \& Education, 6(1), 9-32.

Bentler, P. M., \& Chou, C. P. (1987). Practical issues in structural modeling. Sociological Methods \& Research, 16(1), 78-117.

Beyond Sport (2013). BeyondSport.org. Retrieved August 25, 2013, from http://http://www.beyondsport.org/

Bodet, G., \& Bernache-Assollant, I. (2011). Consumer loyalty in sport spectatorship services: the relationships with consumer satisfaction and team identification. Psychology \& Marketing, 28(8), 781-802.

Cable, D. M., \& DeRue, D. S. (2002). The convergent and discriminant validity of subjective fit perceptions. Journal of Applied Psychology, 87(5), 875-884.

Cammann, C., Fichman, M., Jenkins, G. D., Jr., \& Klesh, J. R. (1983). Assessing the attitudes and perceptions of organizational members. In S. E. Seashore, E. E. Lawler, P. H. Mirvis, \& C. Cammann (Eds.), Assessing organizational change: A guide to methods, measures, and practices (pp. 71-138). New York, NY: Wiley.

Chalip, L. (2006). Toward a distinctive sport management discipline. Journal of Sport Management, 20, 1-21.

Chatman, J. A. (1989). Improving interactional organizational research: A model of personorganization fit. Academy of Management Review, 14(3), 333-349.

Cohen, J. (1988). Statistical power analysis for the behavioral sciences (2nd ed.). Hillsdale, NJ: Lawrence Erlbaum.

Dillman, D. A., Smyth, J. D., \& Christian, L. M. (2009). Internet, mail, and mixed-mode surveys: the tailored design method (3rd ed.). Hoboken, NJ: John Wiley \& Sons.

Dimmock, J. A., \& Grove, J. R. (2005). Relationship of fan identification to determinants of aggression. Journal of Applied Sports Psychology, 17(1), 37-47.

Dutton, J. E., Dukerich, J. M., \& Harquail, C. V. (1994). Organizational images and member identification. Administrative Science Quarterly, 39(2), 239-263. 
Edwards, M. R., \& Peccei, R. (2010). Perceived organizational support, organizational identification, and employee outcomes testing a simultaneous multifocus model. Journal of Personnel Psychology, 9(1), 17-26.

Efraty, D., \& Wolfe, D. M. (1988). The effect of organizational identification on employee affective and performance responses. Journal of Business and Psychology, 3(1), 105-112.

Fisher, R. J. (1998). Group-derived consumption: the role of similarity and attractiveness in identification with a favorite sports team. Advances in Consumer Research, 25, 283-288.

Fisher, R. J., \& Wakefield, K. (1998). Factors leading to group identification: A field study of winners and losers. Psychology \& Marketing, 15(1), 23-40.

Forbes (2012, August). Why you need dissatisfied employees. Retrieved October 12, 2013, from http://www.onforbes.es/P93uc7

Fornell, C., \& Larcker, D. (1981). Structural equation models with unobservable variables and measurement error. Journal of Marketing Research, 18(3), 382-388.

Frone, M. R., Russell, M., \& Cooper, M. L. (1995). Job stressors, job involvement and employee health: A test of identity theory. Journal of Occupational and Organizational Psychology, 68(1), 1-11.

Govindarajan, V., \& Kopalle, P. K. (2006). Disruptiveness of innovations: Measurement and an assessment of reliability and validity. Strategic Management Journal, 27(2), 189-199.

Grant, A. M. (2008). Does intrinsic motivation fuel the prosocial fire? Motivational synergy in predicting persistence, performance, and productivity. Journal of Applied Psychology, 93(1), 48-58.

Griepentrog, B. K., Harold, C. M., Holtz, B. C., Klimoski, R. J., \& Marsh, S. M. (2012). Integrating social identity and the theory of planned behavior: Predicting withdrawal from an organizational recruitment process. Personnel Psychology, 65(4), 723-753.

Hackman, J. R., \& Oldham, G. R. (1980). Work redesign. Philippines: Addison-Wesley.

Hair, J. F., Black, W. C., Babin, B. J., Anderson, R. E., \& Tatham, R. L. (2006). Multivariate data analysis (6th ed.). Upper Saddle River, NJ: Pearson Education.

Heck, T. (2009, September 5). Bleacher Report. Retrieved August 25, 2013, from http://bleacher report.com/articles/171545-detroit-pistons-hall-of-fame-coach-chuck-daly-dead-at-78

Henrich, J., \& Gil-White, F. J. (2001). The evolution of prestige: Freely conferred deference as a mechanism for enhancing the benefits of cultural transmission. Evolution and Human Behavior, 22(3), 165-196.

Hogg, M. A. (2006). Social identity theory. In P. J. Burke (Ed.), Contemporary social psychological theories (pp. 111-136). Palo Alto: Stanford University Press.

Holtz, B. C., \& Harold, C. M. (2008). When your boss says no! the effects of leadership style and trust on employee reactions to managerial explanations. Journal of Occupational and Organizational Psychology, 81(4), 777-802.

Holtz, B. C., \& Harold, C. M. (2009). Fair Today, Fair Tomorrow? A longitudinal investigation of overall justice perceptions. Journal of Applied Psychology, 94(5), 1185-1199.

Hulland, J. (1999). Use of partial least squares (PLS) in strategic management research: A review of four recent studies. Strategic Management Journal, 20, 195-204.

Jiang, J. T., Klein, G., \& Carr, C. L. (2002). Measuring information system service quality: SERVQUAL from the other side. MIS Quarterly, 26(2), 145-166.

Jordan, J. S., Walker, M., Kent, A., \& Inoue, Y. (2011). The frequency of nonresponse analyses in the Journal of Sport Management. Journal of Sport Management, 25(3), 229-239. 
Kanungo, R. N. (1982). Measurement of job and work involvement. Journal of Applied Psychology, 67, 341-349.

Kline, R. B. (2005). Principles and practice of structural equation modeling (2nd ed.). New York, NY: Guilford.

Kristof, A. L. (1996). Person-organization fit: An integrative review of its conceptualizations, measurement, and implications. Personnel Psychology, 49(1), 1-49.

Kristof-Brown, A. L., \& Guay, R. P. (2011). Person-environment fit. In S. Zedeck (Ed.), APA handbook of industrial and organizational psychology (Vol. 3, pp. 3-50). Washington, DC: APA.

Kuenzel, S., \& Vaux Halliday, S. (2008). Investigating antecedents and consequences of brand identification. Journal of Product and Brand Management, 17(5), 293-304.

Lacey, R., Close, A. G., \& Finney, R. Z. (2010). The pivotal roles of product knowledge and corporate social responsibility in event sponsor effectiveness. Journal of Business Research, 63(11), 1222-1228.

Lambert, S. J. (1991). The combined effects of job and family characteristics on the job satisfaction, job involvement, and intrinsic motivation of men and women workers. Journal of Organizational Behavior, 12(4), 341-363.

Lavelle, J. J., Rupp, D. E., \& Brockner, J. (2007). Taking a multifoci approach to the study of justice, social exchange, and citizenship behavior: the target similarity model. Journal of Management, 33(6), 841-866.

Leedy, D. L., \& Ormrod, J. E. (2001). Practical Research (7th ed.). Upper Saddle River, NJ: Prentice-Hall.

Madrigal, R. (2000). The influence of social alliances with sports teams on intentions to purchase corporate sponsors' products. Journal of Advertising, 29(4), 13-27.

Mael, F. A., \& Ashforth, B. E. (1992). Alumni and their alma mater: A partial test of the reformulated model of organizational identification. Journal of Organizational Behavior, 13(2), 103-123.

Mael, F. A., \& Ashforth, B. E. (2001). Identification in Work, War, Sports, and Religion: Contrasting the Benefits and Risks. Journal for the Theory of Social Behaviour, 31(2), $197-222$.

Mael, F. A., \& Tetrick, L. E. (1992). Identifying organizational identification. Educational and Psychological Measurement, 52(4), 813-824.

Marique, G., \& Stinglhamber, F. (2011). Identification to proximal targets and affective organizational commitment. Journal of Personnel Psychology, 10(3), 107-117.

Marique, G., Stinglhamber, F., Desmette, D., Caesens, G., \& De Zanet, F. (2013). The relationship between perceived organizational support and affective commitment: A social identity perspective. Group \& Organization Management, 38(1), 68-100.

Meyer, J. P., Allen, N. J., \& Smith, C. A. (1993). Commitment to organizations and occupations: Extension and test of a three-component conceptualization. Journal of Applied Psychology, 78(4), 538-551.

Mintzberg, H. (1979). The structuring of organizations. Englewood Cliffs, NJ: Prentice-Hall.

Muthén, L. K.., \& Muthén, B. O. (1998-2012). Mplus User's Guide (7th Ed.). Los Angeles, CA: Muthén \& Muthén.

O’Neil, M. (June 18, 2014). Volunteer opportunities help employers attract talent, report says. The Chronicle of Philanthropy. Retrieved from http://philanthropy.com/article/\%20Volunteer-\%20Opportunities-Help/147205/. 
Paullay, I. M., Alliger, G. M., \& Stone-Romero, E. F. (1994). Construct validation of two instruments designed to measure job involvement and work centrality. Journal of Applied Psychology, 79(2), 224-228.

Podsakoff, P. M., MacKenzie, S. B., Lee, J., \& Podsakoff, N. P. (2003). Common method biases in behavior research: A critical review of the literature and recommended remedies. Journal of Applied Psychology, 88(5), 879-903.

Pritchard, M. P., Stinson, J., \& Patton, E. (2010). Affinity and affiliation: the dual-carriage way to team identification. Sport Marketing Quarterly, 19(2), 67-77.

Rich, B. L., Lepine, J. A., \& Crawford, E. R. (2010). Job engagement: Antecedents and effects on job performance. Academy of Management Journal, 53(3), 617-635.

Riketta, M. (2005). Organizational identification: A meta-analysis. Journal of Vocational Behavior, 66(2), 358-384.

Schaubroeck, J., Lam, S. S., \& Peng, A. C. (2011). Cognition-based and affect-based trust as mediators of leader behavior influences on team performance. Journal of Applied Psychology, 96(4), 863-871.

Skudiene, V., \& Auruskeviciene, V. (2006). The contribution of corporate social responsibility to internal employee motivation. Baltic Journal of Management, 7(1), 49-67.

Sluss, D. M., Ashforth, B. E., \& Gibson, K. R. (2012). The search for meaning in (new) work: Task significance and newcomer plasticity. Journal of Vocational Behavior, 81(2), 199208.

Stam, W., \& Elfring, T. (2008). Entrepreneurial orientation and new venture performance: the moderating role of intra- and extraindustry social capital. Academy of Management Journal, 51(1), 97-111.

Stamper, C. L., \& Masterson, S. S. (2002). Insider or outsider? How employee perceptions of insider status affect their work behavior. Journal of Organizational Behavior, 23(8), 875.

Tajfel, H., \& Turner, J. C. (1986). The social identity theory of intergroup behavior. In S. Worchel \& W. G. Austin (Eds.), Psychology of intergroup relations (pp. 7-24). Chicago: Nelson-Hall.

Thompson, J. D. (1967). Organization in action. New York: McGraw Hill.

Todd, S., \& Kent, A. (2009). A social identity perspective on the job attitudes of employees in sport. Management Decision, 47(1), 173-190.

Todd, S. Y., \& Andrew, D. P. S. (2008). An exploratory investigation of sport management students' attraction to sport jobs. International Journal of Sport Management and Marketing, 4(4), 323-337.

Trail, G. T., Robinson, M. J., Dick, R. J., \& Gillentine, A. J. (2003). Motives and points of attachment: Fans versus spectators in intercollegiate athletics. Sport Marketing Quarterly, 12(4), 217-227.

Tsiotsou, R. (2012). Developing a scale for measuring the personality of sport teams. Journal of Services Marketing, 26(4), 238-252.

Turner, J. C. (1984). Social identification and psychological group formation. In H. Tajfel (Ed.), The social dimension: European developments on social psychology (Vol. 2, pp. 518538). Cambridge, UK: Cambridge University Press.

Van Knippenberg, D., \& Van Schie, E. C. M. (2000). Foci and correlates of organizational identification. Journal of Occupational and Organizational Psychology, 73(2), 137-147.

Vora, D., \& Kostova, T. (2007). A model of dual organizational identification in the context of the multinational enterprise. Journal of Organizational Behavior, 28(3), 327-350. 
Walker, M., \& Kent, A. (2009). Do fans care? Assessing the influence of corporate social responsibility on consumer attitudes in the sport industry. Journal of Sport Management, 23(6), 743-769.

Wann, D. L. (1997). Sport Psychology. Upper Saddle River, NJ: Prentice-Hall, Inc.

Wann, D. L. (2006). The causes and consequences of sport team identification. In A. A. Raney \& J. Bryant (Eds.), Handbook of sports and media (pp. 331-352). Mahwah, NJ: Erlbaum.

Wann, D. L., \& Branscombe, N. R. (1990). Die-hard and fair-weather fans: Effects of identification on BIRGing and CORFing tendencies. Journal of Sport and Social Issues, 14(2), 103-117.

Wann, D. L, \& Branscombe, N. R. (1993). Sports fans: Measuring degree of identification with their team. International Journal of Sport Psychology, 24, 1-17.

Wann, D. L., Carlson, J. D., \& Schrader, M. P. (1999). The impact of team identification on the hostile and instrumental verbal aggression of sport spectators. Journal of Social Behavior and Personality, 14(2), 279-286.

Wann, D. L., Dolan, T. J., McGeorge, K. K., \& Allison, J. A. (1994). Relationships between spectator identification and spectators' perceptions of influence, spectators' emotions, and competition outcome. Journal of Sport \& Exercise Psychology, 16(4), 347-364.

Wann, D.L., Haynes, G., McLean, B., \& Pullen, P. (2003). Sport team identification and willingness to consider anonymous acts of hostile aggression. Aggressive behavior, 29(5), 406-413.

Weiss, H. M. (2002). Deconstructing job satisfaction: Separating evaluations, beliefs and affective experiences. Human Resource Management Review, 12(2), 172-194.

Wieseke, J., Kraus, F., Ahearne, M., \& Mikolon, S. (2012). Multiple identification foci and their countervailing effects on salespeople's negative headquarters stereotypes. Journal of Marketing, 76(3), 1-20. 


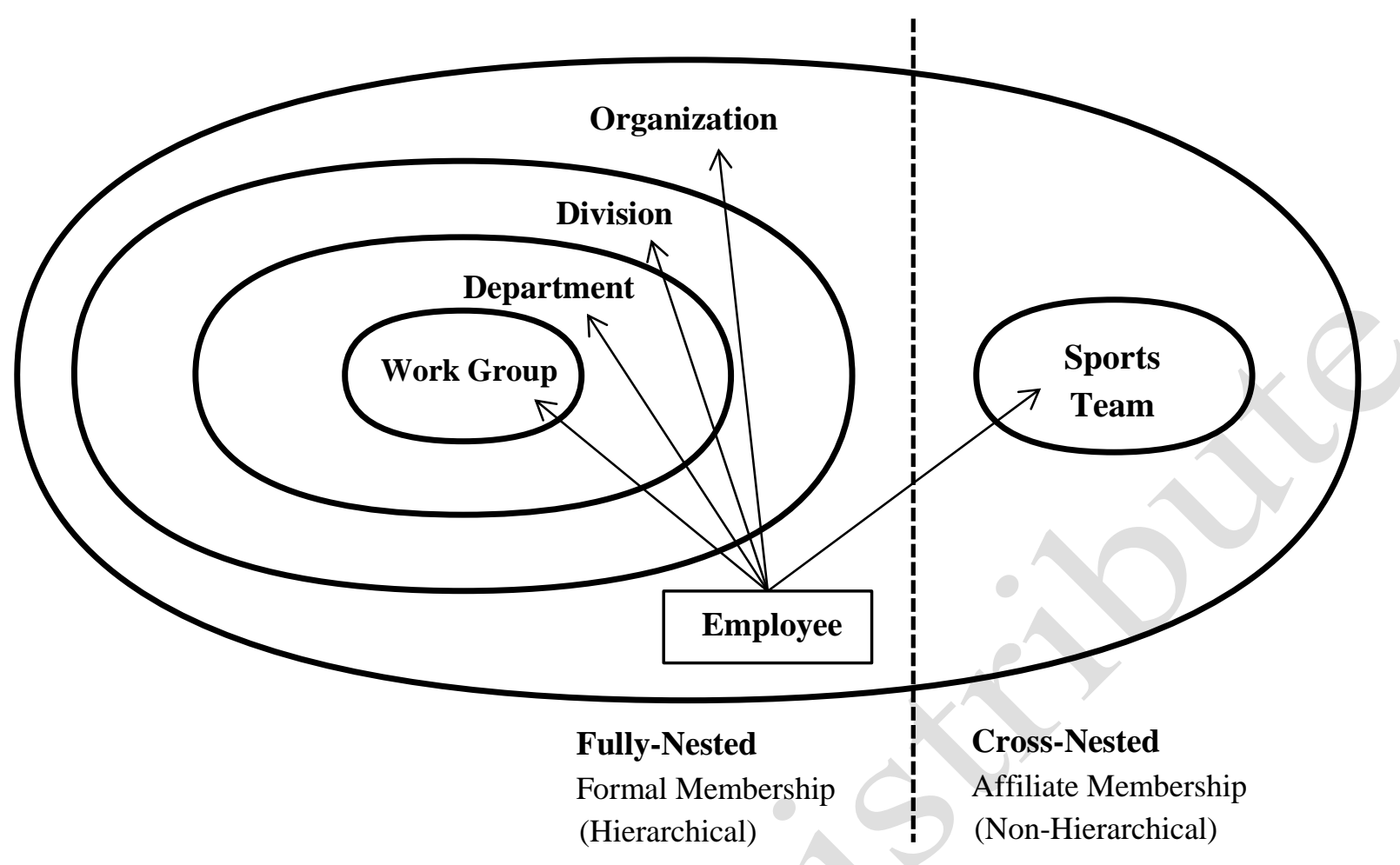

Figure 1. Foci of Identification in Team Sport Organizations

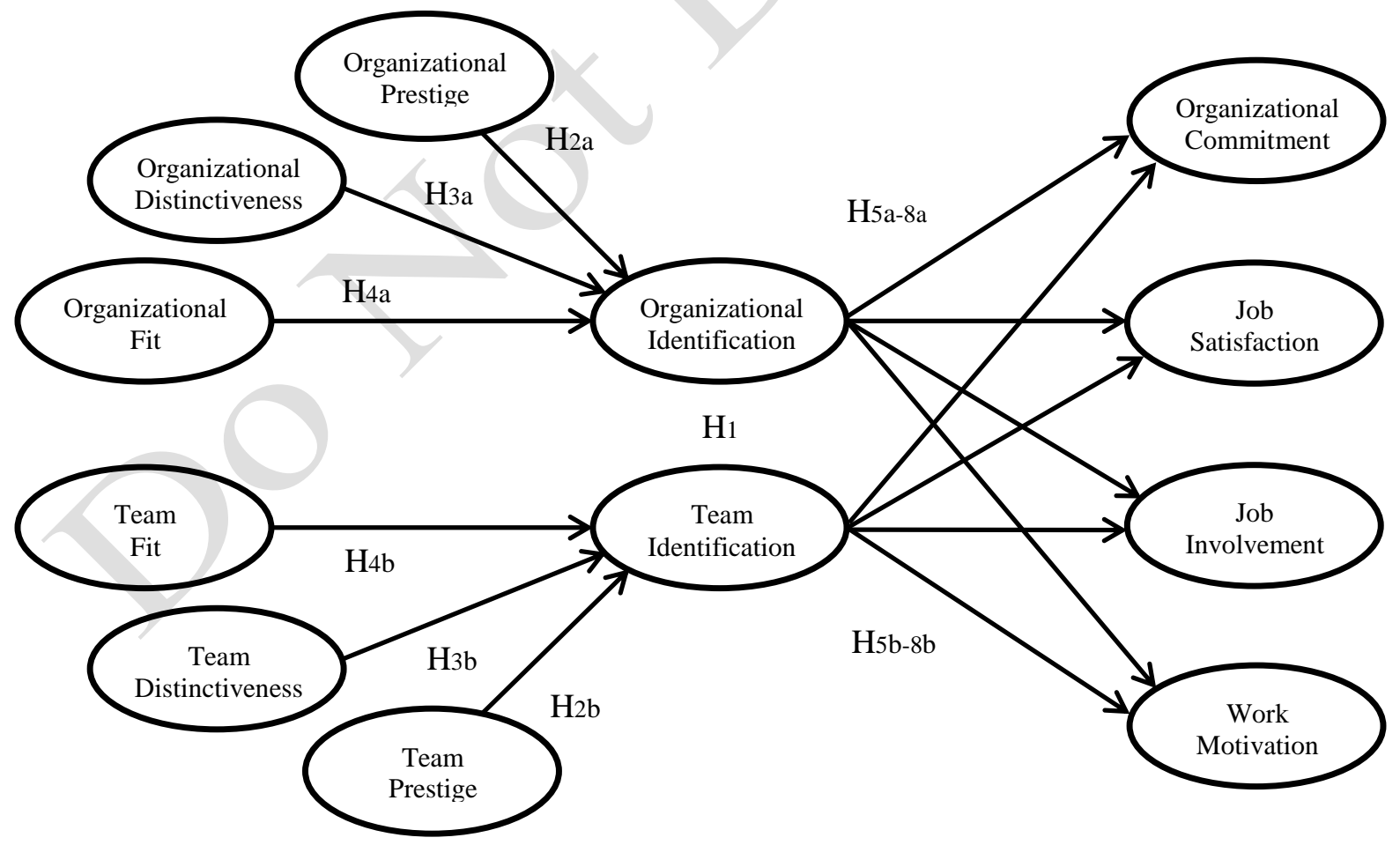

Figure 2. A model of dual identification in professional team sport organizations 
Table 1. Correlations and Internal Consistency Reliabilities

\begin{tabular}{|c|c|c|c|c|c|c|c|c|c|c|c|c|c|}
\hline & & 1 & 2 & 3 & 4 & 5 & 6 & 7 & 8 & 9 & 10 & 11 & 12 \\
\hline 1. & Org. ID & .80 & & & & & & & & & & & \\
\hline 2. & Team ID & $.33^{*}$ & .84 & & & & & & & & & & \\
\hline 3. & Org. Prestige & $.24^{*}$ & $.19^{*}$ & .89 & & & & & & & & & \\
\hline 4. & Team Prestige & $.18^{*}$ & $.20^{*}$ & $.72^{*}$ & .85 & & & & & & & & \\
\hline 5. & Org. Distinct. & $.35^{*}$ & $.29^{*}$ & $.46^{*}$ & $.32^{*}$ & .78 & & & & & & & \\
\hline 6. & Team Distinct. & $.29^{*}$ & $.41^{*}$ & $.37^{*}$ & $42^{*}$ & $56^{*}$ & .82 & & & & & & \\
\hline 7. & Org. Fit & $.39^{*}$ & $.35^{*}$ & $.49^{*}$ & $.36^{*}$ & $.55^{*}$ & $.42^{*}$ & .96 & & & & & \\
\hline 8. & Team Fit & $.36^{*}$ & $.40^{*}$ & $.41^{*}$ & $.42^{*}$ & $.44^{*}$ & $.54^{*}$ & $.63^{*}$ & & & & & \\
\hline 9. & Affect. Commit. & $.46^{*}$ & $.49^{*}$ & $.41^{*}$ & $.47^{*}$ & $.66^{*}$ & $.28^{*}$ & $.41^{*}$ & $.53^{*}$ & & & & \\
\hline 10. & Job Sat. & $.31^{*}$ & $.33^{*}$ & $.38^{*}$ & $.37^{*}$ & $.55^{*}$ & $.27^{*}$ & $.28^{*}$ & $.37^{*}$ & $.64^{*}$ & .85 & & \\
\hline 11. & Job Involve. & $.29^{*}$ & $.34^{*}$ & $.13^{*}$ & $.27^{*}$ & $.34^{*}$ & $.11^{*}$ & $.26^{*}$ & $.34^{*}$ & $.44^{*}$ & $.37^{*}$ & .88 & \\
\hline 12. & Work Motiv. & $.28^{*}$ & $.29^{*}$ & $.25^{*}$ & $.32^{*}$ & $.39^{*}$ & $.18^{*}$ & $.24^{*}$ & $.30^{*}$ & $.49^{*}$ & $.64^{*}$ & $.48^{*}$ & .92 \\
\hline
\end{tabular}

Table 2. Factor Loadings of the Identification Constructs

\begin{tabular}{lcc}
\hline & \multicolumn{2}{c}{ Factor loadings $(\beta)$} \\
\cline { 2 - 3 } Construct / Items & Original & Revised \\
\hline $\begin{array}{l}\text { Organizational Identification } \\
\text { (OID) }\end{array}$ & & \\
OID1 & $.67^{*}$ & $.67^{*}$ \\
OID2 & $.66^{*}$ & $.66^{*}$ \\
OID3 & $.55^{*}$ & $.55^{*}$ \\
OID4 & $.69^{*}$ & $.69^{*}$ \\
OID5 & $.76^{*}$ & $.76^{*}$ \\
OID6 & $.52^{*}$ & $.52^{*}$ \\
Team Identification (TID) & & \\
TID1 & $.54^{*}$ & $.54^{*}$ \\
TID2 & $.91^{*}$ & $.92^{*}$ \\
TID3 & $.85^{*}$ & $.85^{*}$ \\
TID4 & $.63^{*}$ & $.63^{*}$ \\
TID5 & $.79^{*}$ & $.78^{*}$ \\
TID6 & $.41^{*}$ & $\mathrm{n} / \mathrm{a}$ \\
TID7 & $.59^{*}$ & $.59^{*}$ \\
\hline${ }^{*} p<.05$ & & \\
& &
\end{tabular}




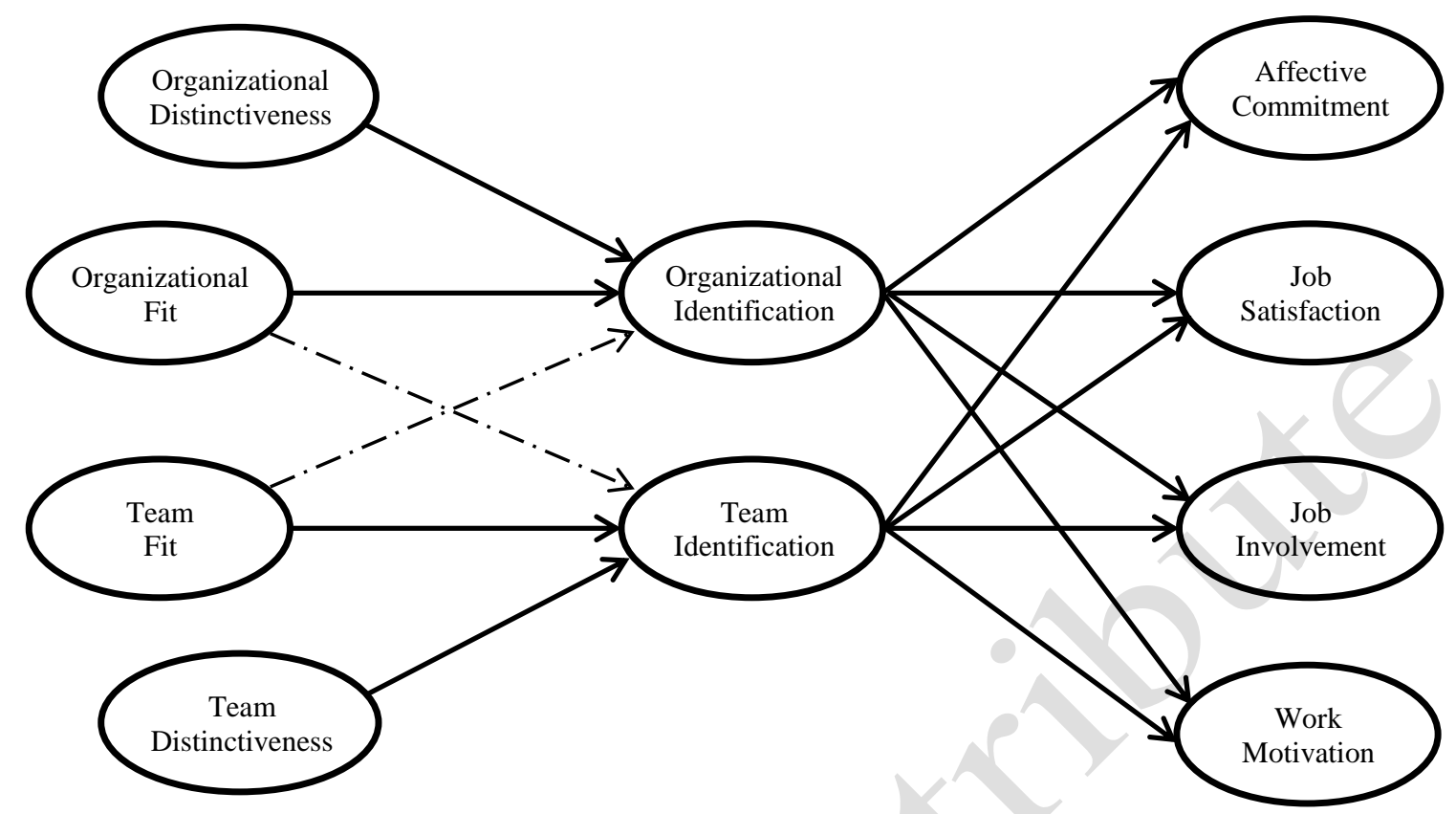

Figure 3. Final Structural Model. Note: Only significant paths are shown. Dashed lines represent cross-foci effects.

Table 3. Standardized Results of Final Structural Model

\begin{tabular}{lllc}
\hline \multicolumn{1}{c}{ Path } & $\beta$ & $R^{2}$ \\
\hline H3a & Organizational Distinctiveness $\rightarrow$ Organizational Identification & .19 & \\
H4a & Organizational Fit $\rightarrow$ Organizational Identification & .29 & \\
& Team Fit $\rightarrow$ Organizational Identification & \\
H3b & Team Distinctiveness $\rightarrow$ Team Identification & .19 & .34 \\
H4b & Team Fit $\rightarrow$ Team Identification & .25 & \\
& Organizational Fit $\rightarrow$ Team Identification & .19 & \\
H5a & Organizational Identification $\rightarrow$ Affective Commitment & .17 & .29 \\
H5b & .47 & \\
H6a & Organizational Identification $\rightarrow$ Job Satisfaction & .43 & .52 \\
H6b & Team Identification $\rightarrow$ Job Satisfaction & .35 & \\
H7a & Organizational Identification $\rightarrow$ Job Involvement & .29 & .27 \\
H7b & Team Identification $\rightarrow$ Job Involvement & .27 & \\
H8a & Organizational Identification $\rightarrow$ Work Motivation & .29 & .21 \\
H8b & Team Identification $\rightarrow$ Work Motivation & .29 & \\
\hline
\end{tabular}

Note: $\beta=$ Standardized path coefficients. ${ }^{*}$ Unhypothesized cross-foci effect. All values are significant $(p<.001)$. 